This work has been submitted to NECTAR, the Northampton Electronic Collection of Theses and Research.

\title{
Article
}

Title: Extent, frequency and rate of water erosion of arable land in Britain benefits and challenges for modelling

Creators: Evans, R., Collins, A. L., Foster, I. D. L., Rickson, R. J., Anthony, S. G., Brewer, T., Deeks, L., Newell-Price, J. P., Truckell, I. G. and Zhang, Y.

Example citation: Evans, R., Collins, A. L., Foster, I. D. L., Rickson, R. J., Anthony, S. G., Brewer, T., Deeks, L., Newell-Price, J. P., Truckell, I. G. and Zhang, Y. (2015) Extent, frequency and rate of water erosion of arable land in Britain - benefits and challenges for modelling. Soil Use and Management. 14752743. (In Press)

It is advisable to refer to the publisher's version if you intend to cite from this work.

Version: Accepted version

Official URL: http://onlinelibrary.wiley.com/doi/10.1111/sum.12210/pdf

Note: This is the peer reviewed version of the following article: Evans, R., Collins, A. L., Foster, I. D. L., Rickson, R. J., Anthony, S. G., Brewer, T., Deeks, L., Newell-Price, J. P., Truckell, I. G. and Zhang, Y. (2015) Extent, frequency and rate of water erosion of arable land in Britain - benefits and challenges for modelling. Soil Use and Management. 1475-2743, which has been published in final form at http://dx.doi.org/10.1111/sum.12210. This article may be used for non-commercial purposes in accordance with Wiley Terms and Conditions for Self-Archiving.

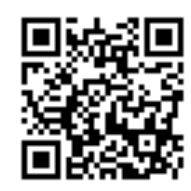




\section{Extent, frequency and rate of water erosion of arable land in Britain - benefits and challenges for modelling}

R. Evans ${ }^{1 *}$, A. L. Collins², I.D.L Foster ${ }^{3}{ }^{4}$, R. J. Rickson ${ }^{5}$, S. G. Anthony ${ }^{6}$, T. Brewer ${ }^{7}$, L. Deeks $^{7}$, J. P. Newell-Price ${ }^{8}$, I.G Truckell ${ }^{7}$, Y Zhang²

7

${ }^{1}$ Global Sustainability Institute, Anglia Ruskin University, East Road, Cambridge, CB1 1PT,

$9 U K$

*Corresponding author email: robert.evans@anglia.ac.uk

${ }^{2}$ Sustainable Soils and Grassland Systems Department, Rothamsted Research, North Wyke,

Okehampton, Devon, EX20 2SB, UK

${ }^{3}$ Environment and Geographical Sciences, University of Northampton, Avenue Campus, St

George's Avenue, Northampton, NN2 6JD, UK

${ }^{4}$ Department of Geography, Rhodes University, Grahamstown 6140, Eastern Cape, South

Africa

${ }^{5}$ National Soil Resources Institute, Cranfield University, College Road, Cranfield,

Bedfordshire, MK43 OAL, UK

${ }^{6}$ ADAS Group Ltd, HQ Pendeford House, Pendeford Business Park, Wolverhampton, WV9 $5 A P, U K$

${ }^{7}$ Cranfield Soil and Agrifood Institute, School of Energy, Environment and Agrifood,

Cranfield University, College Road, Cranfield, Bedfordshire, MK43 OAL, UK

${ }^{8}$ Adas Gleadhtorpe Grange, Meden Vale, Mansfield, NG20 9PD, UK

Running title: Challenges for modelling soil erosion 


\section{Abstract}

Soil erosion on arable land in lowland Britain has been the subject of field-based surveys which assessed the volumes or masses of soil transported across the farmers' field through channels. These surveys provide a unique database on the extent, frequency and rates of soil loss by water. This paper synthesizes the key learning from those surveys and underscores implications for soil erosion modelling. Rill erosion occurs in a small number of fields (consistently less than 10\%), not everywhere. Over time steps of $\sim 5$ years, a considerable part of the farmed landscape will suffer soil erosion by rilling but mostly in fields that erode only once. Mean erosion rates for lowland arable landscapes are much less than mean erosion rates for individual eroded fields within that landscape. These observations pose important challenges for modelling. Rainfall and cropping vary from year to year so that risk of wash or rill erosion in the same field also varies. Due to the infrequent occurrence of rilling rates of eroding fields cannot be spatially extrapolated across the landscape, except in the case of wash. Wash erosion takes place a number of times in almost all fields every year. A consistent pattern of increasing wash, in terms of spatial extent, is emerging in lowland Britain. Such losses of fine silt and clay-sized particles are small in amount and possibly insignificant in terms of loss of soil as a resource but have significant implications for contaminant concentrations and pollution of water courses.

Key words: Water erosion, extent, frequency, rates, field-based assessment, modelling

\section{Introduction}

Mitigating runoff and soil erosion is high on the government's agenda presently (Evans, 2010a). It is important to protect a precious resource, the soil - as exemplified by the proposal for a Thematic Strategy for Soil Protection (Council of European Communities, 2006), including a Soil Framework Directive, later withdrawn after lobbying but considered likely to 
re-emerge in the near future. Apart from inputs of organic matter to the mineral matrix soil can, with regard to its minerogenic constituents, best be considered over the short term as non-renewable. Reduction of excessive soil erosion is also especially important to protect water courses from agricultural diffuse pollution including sediment (Collins et al., 2009 \& 2011) in the context of the European Union Water Framework Directive (Council of European Communities, 2000) which seeks to deliver good ecological status in freshwaters. As well as impacting detrimentally on aquatic ecology (Kemp et al., 2011; Jones et al., 2012a \& 2012b) diffuse pollution is a serious problem for the Water Industry. To assess how excessive runoff and soil erosion can be tackled on farm, and to test the efficiency of available mitigating options, a realistic baseline assessment of erosion is needed. The baseline assessment should not only describe typical rates of soil erosion in arable fields, but also the extent of land affected by water erosion within a locality (soil landscape) and the corresponding frequency of erosion; do fields erode frequently or rarely? On the basis of these principal requirements - rate, extent and frequency of erosion of arable fields within soil landscapes, information gathered in the field across lowland Britain on the extent, frequency and rate of soil erosion on arable land is synthesized to give an understanding of baseline soil erosion across lowland arable Britain. Such a baseline can be used to validate models constructed to simulate erosion rates or risk and to assess the efficacy of mitigation options. The implications of the empirical data for soil loss by water on arable land are discussed.

We do not include estimates of soil erosion based on the widespread use of fallout radionuclides (FRNs) in England and Wales, especially Cs-137. While a large literature suggests that available conversion models provide realistic estimates of erosion rates (see Zapata, 2002; IAEA, 2014 for reviews of methodology), there is a growing body of evidence to suggest the technique is flawed because it cannot be shown that some of the fundamental 
underlying assumptions are met, for example that Cs-137 was evenly deposited across the catchment from the grass field on the watershed to the arable field on the lower slopes or that the models used to convert Cs-137 measurements to rates of erosion are adequate (e.g.

Dalgleish \& Foster, 1996; Parsons \& Foster, 2011 \& 2013). Models to predict erosion based on similar underlying assumptions to those used to convert Cs-137 measurements to rates of erosion do not reflect what is found in the field (Evans \& Brazier, 2005). The limited number of comparisons between Cs-137 and field based estimates of erosion currently suggest that the use of FRNs over predicts erosion rates to a significant but inconsistent and unpredictable amount. This conclusion is drawn from a comparison of estimated amounts of soil eroded across soil landscapes (soil associations; SSEW, 1983) with maps of amounts of erosion estimated using Cs-137 (Exeter University, 2008; Walling \& Zhang, 2010). Estimates of amounts of soil eroded within soil landscapes (available on request) are based on rates and extent of erosion within soil landscapes monitored for erosion in the SSEW project (Evans, $1988,1990,1993 \& 2005$, and see below). In the monitoring scheme eroded fields were found in 62 of the 196 soil associations (31.6\%) covering lowland England and Wales. Amounts eroded are estimated for soil landscapes based on their soils, land use and topography as described in the legend for the National Soil Map (SSEW, 1983), and Evans' classification of erosion risk (Evans, 1990; Figure 1) assuming the midpoint in range of values of extent of erosion in each class and mean rate of erosion for fields with topsoil textures similar to those obtained in the monitoring scheme.

Soil erosion assessed in farmers' fields is generally in the form of channels - rills or larger features which cannot be erased by cultivation (gullies), although they can also be very small features referred to as traces, very short, shallow features often ending in a small sediment deposition fan (Colborne \& Staines, 1986). Evidence of runoff can often be seen as flow-lines of deposited sediment particles, usually fine sand, coarse silt or organic particles or debris. 
The mobilisation of soil particles separated out by rain splash and transported a short distance by low velocity runoff which does not attain sufficient force to incise into the soil is referred to here as wash (Evans, 2013). Much of the erosion described here is of the more visually obvious sort in the farmers' field, rill or gully erosion (Evans, 2013), not traces or wash.

\section{Extent of soil erosion}

Between 1982 and 1986, 17 localities across England and Wales were monitored for rill and gully erosion (Evans, 2005), a project set up by the then Soil Survey of England and Wales to assess if soil erosion was a problem. The 17 localities are described in more detail elsewhere (Evans, 1988), as are the results of monitoring (e.g. Evans, 1993 \& 1996).The localities were chosen because it was suspected they were vulnerable to soil erosion or may become more vulnerable to erosion if land use changed, for example, from grassland to arable (Devon, Cumbria). Aerial photographs were taken of the localities and these transects sometimes covered more than the soil landscape considered most at risk of soil erosion. Eroded fields were identified on the photographs and the interpretations checked in the field. To these were added fields eroded after the aerial photographs were taken or not identified initially. Just over 1700 eroded fields were located.

The areas of eroded fields in the soil landscapes (SSEW, 1983) covered in the 'core' area photographed each year was estimated and expressed as a percentage of the total farmland on the transect (Figure 2a) or the soil landscapes (Figure 2b). The 'core area' is the area photographed every year, as the area covered by each transect varied somewhat from year to year as the flight line and height above ground of the aircraft were not always exactly the same.

Overall, just over $4 \%$ of farmland was eroded by rills and gullies and in no locality was $10 \%$ eroded, although individual landscapes within localities could suffer more soil erosion. Those 
localities or associations in which more than $4 \%$ of the landscape eroded had soils with high sand or coarse silt contents, and a greater proportion of their landscape covered by arable land growing both autumn- and spring-sown crops. Less vulnerable landscapes had more grassland and often heavier textured soils. In individual years, soil erosion could be more extensive in more vulnerable landscapes (Figure 2c), when over $20 \%$ of farmland could erode. Within field, the area covered by rills and sediment deposition, on average, was rarely more than $1 \%$ (Kent, Isle of Wight), though as much as $18 \%$ in individual fields (Isle of Wight).

Boardman (1988 \& 2003) monitored $36 \mathrm{~km}^{2}$ of hilly chalk Downland with mostly shallow silty (Andover 1 Soil Association; SSEW, 1983) soils in West Sussex between 1982 and 1991. A part of this area was also covered by a monitored aerial photograph transect (Figure 2b; Suss $\left.\mathrm{W} 2^{* *}\right)$. On average, $10.3 \%$ of the farmland eroded each year, a higher value than that in the SSEW project for a similar Sussex landscape. Other localities have been monitored in years when it was considered that soil erosion was more widespread than usual (Table 1). Areas of farmland affected by erosion are greater than those recorded in the SSEW project but not greatly so. During the 5 years (1982-86) of the SSEW monitoring scheme no year was particularly outstanding for soil erosion, unlike, for example 1987, when rainfall in autumn on the South Downs was exceptional and gave rise to widespread and severe soil erosion (Boardman, 1988).

On the Sussex Downs, over 6 years (1982-1987), eroded fields covered all together $27 \%$ of the land (after Boardman, 1990) and the mean area of land affected by erosion each year over a 10 year period was $10.3 \%$ (Boardman, $1990 \&$ 2003). For the 17 SSEW landscapes monitored in the 1980s, crude estimates can be made of the total (per cent) area affected by soil erosion, if it is assumed that over the 5 year monitoring period, $70 \%$ of the fields eroded only once (see below). Thus, for a very high risk landscape (Evans, 1990) such as the 
Nottinghamshire sand land, in total over the 5 years about $45 \%$ of the farmed landscape was covered by eroded fields, for other farmed landscapes classified at high risk, between 14 and $28 \%$ of the farmed landscape probably eroded over the 5 years

Soil erosion has been monitored for a similar number of years (3-13) in other localities in Britain (Table 2). The areas monitored were surveyed in years when it was considered erosion was more widespread than usual. The areas affected by soil erosion are not dissimilar to those recorded by the SSEW project. The Sompting catchment in the Sussex South Downs has been monitored by the author for a much longer period, 26 years since 1989 . The $c .10$ $\mathrm{km}^{2}$ catchment eroded severely in the late 1980s and early 1990s after the land use was changed from dominantly grass to dominantly arable land covering $65 \%$ of its area and growing winter cereals, a crop vulnerable to soil erosion (Boardman, 2003; Evans \& Boardman, 2003). Over that time, fields covering $62 \%$ of the catchment suffered erosion, 48 $\%$ in one year before set-aside was brought in (Evans \& Boardman, 2003), and again, many fewer fields after the catchment went back to being predominantly under grass in $2005 / 6$. The latter change came about because of a change in the European Union's Common Agricultural Policy (CAP) and new ownership of the largest farm in the catchment. The average number of fields that suffered soil erosion declined from 12.4 per year to 2.7 (Evans, 2010b).

\section{Frequency of erosion}

There is little published information on the frequency of soil erosion by water in Britain. Most surveys of erosion indicate where eroded fields have been seen - for example, in England and Wales (Evans \& Cook, 1986), Scotland (Speirs \& Frost, 1985) and other sites in Britain (Boardman, 2002) - but do not indicate if the field has eroded in more than one year.

Two areas on the South Downs, Sussex, where autumn-sown cereals were the dominant crop, have been monitored for a number of years (Tables $3 \& 4$ ), some fields eroded frequently. 
The Sompting catchment (Table 4) is probably exceptional in that for many years there was little crop rotation and much of the arable land was sown to winter cereals and grass fields remained under grass. Hence the same fields were drilled every year to winter cereals and were at risk of erosion every year. In most other monitored landscapes (Figure 3), the length of time monitored (3-5 years) is similar to that of Boardman (1988, $1990 \& 2003)$, and the findings are similar, including localities where winter cereals are dominant but also where soils are dominantly sandy and a much wider range of crops was grown. Fields eroded mostly only once in 5 years.

\section{Rates of soil erosion}

Mean rates of soil erosion in fields along a transect (Figure 4a) or within a soil association (Figure 4b) are dominantly less than $5 \mathrm{~m}^{3} / \mathrm{ha}(=6.5 \mathrm{t} / \mathrm{ha}$ if soil bulk density is assumed to be $1.3 \mathrm{~g} / \mathrm{cm}^{3}$ ), and the mean value per transect is related to that of the dominant soil association. Higher mean rates $\left(>2 \mathrm{~m}^{3} / \mathrm{ha},=>2.6 \mathrm{t} / \mathrm{ha}\right)$ are associated with soils containing high proportions of sand or silt. Lowest rates were found in the Bedfordshire locality where soils are clayey and relief is low. Median values are much lower, mostly varying either side of $1 \mathrm{~m}^{3} / \mathrm{ha}(1.3 \mathrm{t} / \mathrm{ha})$. Maximum rates of erosion are often (much) more than 10 times the mean value. As noted previously, soil erosion rates measured in different British field-based monitoring schemes are not dissimilar (Table 5). However, rates are lower in the SSLRC project because the monitoring period was shorter (less chance of erosive rainfalls occurring), higher risk soil landscapes were less sampled and wash as well as rill erosion was taken into account. Rates of soil erosion recorded for other reasons in other locations in Britain (Table 6) often have much lower maximum rates than those recorded in the schemes specifically designed to monitor erosion (Table 5). Soil erosion magnitude and frequency curves derived from data from long running monitoring schemes are also similar (Figure 5; and Boardman, 2003, pp. 180), as small events dominate the distribution and large events are rare. 


\section{Discussion}

Extent, frequency and rates of soil erosion estimated in various lowland locations across

Britain, and at different times, are similar and give a baseline for those monitored locations to assess changes in occurrence and severity of soil erosion by water in arable fields in the future. An earlier classification of soil associations at risk of erosion (Evans, 1990; Figure 1) was confirmed by later fieldwork (Marks et al., 1997). Such targeted empirical work forms the base upon which to validate models that predict erosion (e.g. Collins et al., 2009) or risk of erosion and to assess the technically feasible impacts of options to mitigate runoff and soil erosion. After a number of years $(\sim 5)$ the total number of fields affected by erosion appears to change little but fields erode more frequently, in other words, in a locality where land use is unchanging there is a 'core' of fields that erodes, other fields do not suffer rilling, presumably because those fields have a permanent vegetation cover or slopes are flat, or nearly so with no breaks of slope.

If climate changes in the future as predicted, with storms becoming more intense (Kovats \& Valentini, 2014; pp. 10), it is likely that soil erosion by water will be more severe (McLeod et al., 2012) and probably more extensive (Evans, 1990; pp. 213; Evans, 1996; pp. 89), though severity and extent will depend on the timing of the storms relative to crop cover. Rains falling when the ground is dominantly covered in crop, or in summer when soils are dry, will have less impact; those falling in autumn or spring, when the ground is mostly bare of crop, will have a much greater impact and this can have serious consequences off-site including detrimental impacts on aquatic ecology (Collins et al., 2011; Kemp et al., 2011). However, it will likely be a change in land use that will determine if soil erosion becomes more extensive and possibly more severe (Table 7). A switch from autumn-sown to spring-sown cereals may have little impact, but a further extension of maize, as happened mostly after the SSEW monitoring project and was foreseen by the project, could have a serious impact on both soils 
and water quality. To some degree, this expansion is already happening in conjunction with the use of maize as input to on-farm digestors for energy generation and for feed for the dairy industry. Similarly, if more vegetables or other root crops are grown, the consequences for soil loss are likely to be significant. All these crops have a high risk of erosion when compared to combinable crops. If, as seems sensible, grass leys are introduced into the crop rotation to curtail erosion precautions will need to be taken at time of drilling, for though ley grassland is at very low risk of erosion presently, when it does erode, erosion can be severe (Table 7). If structural degradation due to compaction by machinery or trampling by animals is remedied before drilling the ley, and it is not then intensively grazed, the ley will return more organic matter to the soil and leave a better structured soil after one to three consecutive years under grass, further curtailing runoff and wash erosion. Fields down to outdoor pigs, often after a cereal crop, which become bare of vegetation once the stubble has been trampled and soils have become heavily compacted, are probably at the highest risk of soil erosion (one field in three; Evans, 2006) but the corresponding rates of erosion are unknown, although it can be assumed that these will be high (e.g. Evans, 2013, pp. 109). If the replacement of grass by winter cereals continues in wetter areas of Britain, especially those with more than $750 \mathrm{~mm}$ rainfall a year (Watson \& Evans, 2007), soil erosion will become more widespread.

There are few strategic field-based assessments of water erosion to compare with those discussed here. Rates of erosion in Europe are similar to those described here (Evans, 2002). Prasuhn (2011 \& 2012) monitored 5 localities comprising 203 fields covering 265 ha in lowland arable Switzerland. Soils are permeable cambisols and luvisols over ground moraine and mostly had a high sand content (sandy loams). The range of crops grown was similar to those in Britain (Table 8) but winter cereals and oilseed rape were less extensive than during the SSEW (1982-1986) monitoring scheme (Table 7) and ley grassland and maize more 
widespread. Rates of erosion do not differ greatly in the two countries, and are of the same order of magnitude, although mean rates are below $3 \mathrm{t} / \mathrm{ha}$ in Switzerland but often higher than that in England and Wales. Indeed, rates in Switzerland were $\leq$ half those in the same crop in England and Wales. Hence, erosion in Switzerland was less severe, especially in ley grassland; possibly there was little erosion at the time of drilling. Perhaps less severe erosion in Switzerland is related to smaller field size in the monitored areas; average field size in Switzerland is 1.3 ha, compared with 7.5 ha in the monitored transects in England and Wales. Field size exerts control on runoff pathway length, water velocity and, hence, erosive power. Erosion was more extensive in Switzerland than in landscapes in England, both for the area monitored and within field and that may partly be explained by the extent of wash erosion (Table 8). Wash erosion was not assessed in the SSEW project.

A comparison of estimates of amounts of silt and clay transported out of rilled fields with suspended sediment loads transported in lowland rivers in England suggests that to explain the discrepancy in estimates wash from the land accounts for a further 0.1-0.3 t/ha/yr (Evans, 2006) in addition to silt and clay from rills and gullies. Later work (Evans, 2012) suggests sources of fine sediment other than from the land may also be important, such as road and tracks and eroding channel banks; cleaned out water courses and ditches can be a source of both fine and coarse particles. Sand particles are not often transported out of fields, they are deposited within the field or trapped by the grassed field margin (Evans, 2012), although forecasted changes in rainfall patterns may have impacts on this particle size selectivity. Recent work in the Wissey catchment, central Norfolk, shows that surface runoff, mostly down tractor wheelings (cf. Collins et al., 2013), often carrying very small amounts of soil, can occur up to 10 times a year. Turbid wash has been observed at the end of an $11 \mathrm{~mm}$ rain storm falling on saturated topsoil flowing into a stream from a field allowed to 'tumble down', i.e. revert to a complete grass, weed and moss cover. Palmer and Smith (2013) show 
that soil degradation (e.g. poaching and compaction) accompanied by surface wash is widespread in south western England. Compaction and structural degradation are widespread for many soils across lowland Britain (Evans, 2012; Palmer \& Smith, 2013) and this provides opportunity for soil wash on most arable fields and during most years. Although the amounts of soil transported by wash are often (very) small, except where topsoils contain high amounts of silt, wash also carries other pollutants such as nutrients (nitrate and phosphate) and pesticides both attached to soil particles and in solution.

If the principal aim of a policy instrument or management strategy is to curtail runoff and erosion, it will be best to concentrate on those soil landscapes known to be most at risk of soil erosion by water (Evans, 1990), especially in the context of the need for improved spatial targeting of on-farm mitigation measures to help deliver value for expenditure of tax payers money (e.g. through the Common Agricultural Policy levers). This drive towards improved spatial targeting is reflected in the revised delivery plans for CAP reform 2014-2020 and the introduction of the new Countryside Stewardship scheme in England which will get underway in January 2016. Estimates of amounts of soil eroded across soil landscapes have been made (see above - Introduction). Such estimates are the best currently available and are clearly realistic and of the right order of magnitude indicating that $50 \%$ of the total volume of soil eroded in lowland England and Wales originates from just 14 of 196 soil associations (Table 9).

Soils in these 'at risk' associations contain high contents of sand or silt. They are among the most easily worked in England and Wales and grow a wide range of crops many of which have inherent risk associated with the timings of bare tilled ground and subsequent harvesting and the type of crop grown (e.g. high risk maize, potatoes and salad crops). Thirty soil associations account for $79 \%$ of the estimated total volume of soil eroded in lowland

England and Wales. Some of these landscapes are dominantly down to grass and because of 
that are classed as at low risk of erosion, however the associations cover such a large area that many fields, though small in number proportionately, are at risk of erosion, especially where grass has been converted to arable as in south west England (Marks et al., 1997).

\section{Conclusion}

Field-based assessments of water erosion in lowland Britain delivered by a number of strategic campaigns give a consistent picture of extent, frequency and rates of erosion. These empirical data provide a reliable basis for validating models constructed to predict erosion, or risk of erosion, and for estimating the potential efficiency of on-farm measures to mitigate soil erosion (Newell-Price et al., 2011).

Nonetheless, the empirical evidence base on soil erosion by water on arable land in lowland Britain also provides some key challenges for the modelling community:

- Severe arable soil erosion in Britain is rare. In any one year, rill erosion occurs in a small number of fields (consistently less than $10 \%$ and typically $\sim 4 \%$ ), and not everywhere across the agricultural landscape. This specific soil erosion process domain is therefore spatially constrained at the annual time step. Over time, say 5 years, a considerable part of the landscape will suffer some soil erosion by rilling but mostly in fields that have only eroded once. This implies that soil erosion models need to simulate at least five years of time to capture all the factors that vary over time that control soil erosion at a landscape scale. Over longer periods, more fields will erode, and the same fields will erode more than once, but not frequently.

- Mean erosion rates for lowland arable landscapes therefore are much less than mean erosion rates for individual eroded fields within that landscape (Evans, 2013). This poses a spatial extrapolation challenge for soil erosion modelling in that rates of 
erosion on fields experiencing soil loss cannot be simply extrapolated to all fields across the landscape in any given year.

- In contrast, wash erosion probably takes place a number of times in most fields every year. A consistent pattern of increasing wash is emerging in lowland Britain.

Compaction and structural degradation are driving much of this wash. Capturing this degradation and wash erosion is increasingly important and poses fewer challenges for modelling as extrapolation is simpler and this process domain occurs each year.

- Techniques to mitigate soil erosion by water should be aimed at addressing soil loss during the more severe erosion event, and should be targeted at landscapes more at risk of erosion or at fields growing particular risky crops, for example, widely grown winter cereals and root crops, or less extensively grown but even more vulnerable crops such as maize, field vegetables and rearing outdoor pigs.

- Spatial targeting is much more of a challenge in the case of soil erosion by wash given that this process is now occurring on almost all arable fields each year. Failure to introduce good soil management to help combat wash will hamper managers in delivering reductions in fine sediment, nutrients and pesticides reaching water courses.

- Techniques to mitigate rill erosion will protect and conserve the soil, but, given the growing importance of surface wash, will not necessarily protect water courses from agricultural diffuse pollution. Indeed this may exacerbate the problem as selective transport will deliver only the finest sediment to streams and rivers where contaminant concentrations are frequently highest (i.e. in fine silts and clays).

- The practicalities and economics of protecting water courses if present-day intensive land use continues are daunting. 


\section{Acknowledgements}

The funding support provided by Defra project SP1318 is gratefully acknowledged. Our thanks to Dr John Boardman for making helpful comments on an earlier draft of the paper.

\section{References}

Boardman, J. 1988. Severe erosion on agricultural land in East Sussex, UK October 1987.

Soil Technology 1, 333-348.

Boardman, J. 1990. Soil erosion on the South Downs: A review. In: Soil Erosion on Agricultural Land (eds J. Boardman, I.D.L. Foster \& J.A. Dearing), John Wiley \& Sons Ltd Chichester, pp. 87-105.

Boardman, J. 2002. The need for soil conservation in Britain - revisited. Area 34, 419-427.

Boardman, J. 2003. Soil erosion and flooding on the eastern South Downs, southern England, 1976-2001. Transactions of the Institute of British Geographers New Series 28, 176-196.

Boardman, J. 2015. Extreme rainfall and its impact on cultivated landscapes. In: Stormy Geomorphology (ed S.N. Lane), Special Issue Earth Surface Processes and Landforms, forthcoming.

Boardman, J., Shepheard, M.L., Walker, E. \& Foster, I.D.L. 2009. Soil erosion and riskassessment for on- and off-farm impacts: A test case using the Midhurst area, West Sussex, UK. Journal of Environmental Management 90, 2578-2588.

Chambers, B.J. \& Garwood, T.W.D. 2000. Monitoring of water erosion on arable farms in England and Wales 1990-94. Soil Use and Management 16, 93-99. 
Chambers, B.J., Davies, D.B. \& Holmes, S. 1992. Monitoring of water erosion on arable farms in England and Wales, 1989-90. Soil Use and Management 8, 163-170.

Colborne, J. \& Staines, S.J. 1985. Soil erosion in south Somerset. Journal of Agricultural Science, Cambridge 104, 107-112.

Colborne, J. \& Staines, S.J. 1986. Soil erosion in Somerset and Dorset. SEESOIL 3, 62-71.

Collins, A.L., Anthony, S.G., Hawley, J. \& Turner, T. 2009. The potential impact of projected change in farming by 2015 on the importance of the agricultural sector as a sediment source in England and Wales. Catena 79, 243-250.

Collins, A.L., Naden, P.S., Sear, D.A., Jones, J.I., Foster, I.D.L. \& Morrow, K. 2011. Sediment targets for informing river catchment management: international experience and prospects. Hydrological Processes 25, 2112-2129.

Collins, A.L., Zhang, Y.S., Duethmann, D., Walling, D.E. \& Black, K.S. 2013. Using a novel tracing-tracking framework to source fine-grained sediment loss to watercourses at subcatchment scale. Hydrological Processes 27, 959-974.

Council of European Communities. 2000. Directive on establishing a framework for community action in the field of water policy (2000/60/EC). Official Journal L327.

Council of European Communities. 2006. Proposal for a Directive of the European Parliament and of the Council establishing a framework for the protection of soil and amending Directives 2004.35.EC 2006/0086/COC.

Dalgleish, H.Y. \& Foster, I.D.L. 1996. Cs-137 losses from a loamy surface water gleyed soil (Inceptisol); a laboratory simulation experiment. Catena 26, 227-245. 
Davidson, D.A. \& Harrison, D.J. 1995. The nature, causes and implications of water erosion on arable land in Scotland. Soil Use and Management 11, 63-68.

Deasy, C., Quinton, J.N., Silgram, M., Bailey, A.P., Jackson, B. \& Stevens, C.J. 2010.

Contributing understanding of mitigation options for phosphorus and sediments to a review of the efficiency of contemporary agricultural stewardship measures. Agricultural Systems 103 (2), 105-109.

Evans, R., 1988. Water Erosion in England and Wales. Report to Soil Survey of England and Wales.

Evan, R. 1990. Soils at risk of accelerated erosion in England and Wales. Soil Use and Management 6, 125-131.

Evans, R. 1993. Extent, frequency and rates of rilling of arable land in localities in England and Wales. In: Farm Land Erosion in Temperate Plains Environment and Hills (ed S.

Wicherek), Elsevier Amsterdam, pp. 177-190.

Evans, R. 1996. Soil Erosion and Its Impacts in England and Wales. Friends of the Earth Trust London.

Evans, R. 2005. Monitoring water erosion in lowland England and Wales - A personal view of its history and outcomes. Catena 64, 142-161.

Evans, R. 2006. Land use, sediment delivery and sediment yield in England and Wales. In: Soil Erosion and Sediment Redistribution in River Catchments (eds P.N. Owens \& A.C. Collins), CAB International Wallingford UK, pp. 70-84.

Evans, R. 2010a. Runoff and soil erosion in arable Britain - Changes in perception and policy since 1945. Environmental Science and Policy 13, 141-149. 
Evans, R. 2010b. Land use and accelerated erosion soil erosion by water in a small catchment on the South Downs, West Sussex, England - past and present. In: Landscapes Through the Lens (eds D.C. Cowley, R.A. Standring \& M.J. Abicht), Occasional Publication of the Aerial Archaeology Research Group No 2 Oxbow Books Oxford, pp. 129-142.

Evans, R. 2012. Reconnaissance surveys to assess sources of diffuse pollution in rural catchments in East Anglia, eastern England - implications for policy. Water and Environment Journal 26 (2), 200-211.

Evans, R. 2013. Assessment and monitoring of accelerated water erosion of cultivated land when will reality be acknowledged? Soil Use and Management 29 (1), 105-118.

Evans, R. \& Boardman, J. 2003. Curtailment of muddy floods in the Sompting catchment, West Sussex, southern England. Soil Use and Management 19, 223-231.

Evans, R. \& Brazier, R. 2005. Evaluation of modelled spatially distributed predictions of soil erosion by water versus field-based assessments. Environmental Science \& Policy 8, 493501.

Evans, R. \& Cook, S. 1986. Soil erosion in Britain. SEESOIL 3, 28-59.

Exeter University, 2008. Documenting Soil Erosion Rates on Agricultural Land in England and Wales - Phase 2. Research Report SP0413, Department for Environment, Food and Rural Affairs, London.

Foster, I, Harrison, S. Clark, D. 1997. Soil erosion in the West Midlands. Geography 82 (3), 231-239.

Harrod, T.R. 1998. A systematic approach to national budgets of phosphorus loss through soil erosion and surface runoff at National Soil Inventory (NSI) nodes. Final Project report to 
Ministry of Agriculture, Fisheries and Food, Soil Survey and Land Research Centre Cranfield University

IAEA. 2014. Guidelines for Using Fallout Radionuclides to Assess Erosion and Effectiveness of Soil Conservation Strategies. IAEA-TECDOC-1741. International Atomic Energy Agency Vienna, 2014, 213 pp.

Jones, J.I., Murphy, J.F., Collins, A.L., Sear, D.A. \& Naden P.S. 2012a. The impact of fine sediment on macro-invertebrates. River Research and Applications 28, 1055-1071.

Jones, J.I., Collins, A.L., Naden, P.S. \& Sear, D.A. 2012b. The relationship between fine sediment and macrophytes in rivers. River Research and Applications 28, 1006-1018.

Kemp, P., Sear, D., Collins, A., Naden, P. \& Jones, I. 2011. The impacts of fine sediment on riverine fish. Hydrological Processes 25, 1800-1821.

Kirkbride, M.P. \& Reeves, A.D. 1993. Soil erosion caused by low intensity rainfall in Angus, Scotland. Applied Geography 13, 299-311.

Kovats, S. \& Valentini, R. 2014. Final Draft IPCC WGII ARS Chapter 23 Europe.

Cambridge University Press Cambridge UK.

Macleod, C.J.A., Falloon, P.D., Evans, R. \& Haygarth, P.M. 2012. The effect of climate change on the mobilization of diffuse substances from agricultural systems. In: Advances in Agronomy (ed D.L. Sparks), 115 Burlington Academic Press, pp. 41-77.

Marks, M.J., Solomon, D.R., Johnson, P.A., Watson, R.L., Royle, S.M., Richardson, S.J. \& Goodlass, G. 1997. Soil Protection Studies. Identification of areas of the country at high or very high risk to soil erosion by water. ADAS Report to Ministry of Agriculture, Fisheries and Food. 
Newell-Price, J.P., Harris, D., Chadwick, D.R., Misselbrook, T.H., Taylor, M., Williams, J.R., Anthony, S.G., Duethmann, D., Gooday, R.D., Lord, E.I. \& Chambers, B.J. 2011. "Mitigation Methods User Guide". An Inventory of Mitigation Methods and Guide to their Effects on Diffuse Water Pollution, Greenhouse Gas Emissions and Ammonia Emissions from Agriculture. Prepared as part of Defra project WQ0106, $158 \mathrm{pp}$.

Palmer, R.C. \& Smith, R.P. 2013. Soil structural degradation in SW England and its impact on surface-water runoff generation. Soil Use and Management DOI: 10.1111/sum.12068.

\section{Parsons, A.J. \& Foster, I.D.L. 2011. What does Cs-137 tell us about soil erosion? Earth} Science Reviews 108, 101-113.

Parsons, A.J. \& Foster, I.D.L 2013. The assumptions of science. A reply to Mabit et al. Earth Science Reviews 127, 308-310

Prasuhn, V. 2011. Soil erosion in the Swiss midlands: results of a ten year field survey. Geomorphology 126, 32-41.

Prasuhn, V. 2012. On-farm effects of tillage and crops on soil erosion measured over 10 years in Switzerland. Soil and Tillage Research 120, 137-146.

Reed, A.H. 1979. Accelerated erosion of arable land in the United Kingdom by rainfall and run-off. Outlook on Agriculture 10, 41-48.

Silgram, M., Jackson, D.R., Bailey, A., Quinton, J. \& Stevens, C. 2010. Hillslope scale surface runoff, sediment and nutrient losses associated with tramline wheelings. Earth Surface Processes and Landforms 35, 699-706.

Speirs, R.B. \& Frost, C.A. 1985. The increasing incidence of accelerated water erosion on arable land in the east of Scotland. Research and Development in Agriculture 2, 161-167. 
Soil Survey of England and Wales. 1983. Soil Map of England and Wales. 1:250 000. Soil Survey of England and Wales Harpenden.

Wade, R.J. \& Kirkbride, M.P. 1998. Snowmelt-generated runoff and soil erosion in Fife, Scotland. Earth Surface Processes and Landforms 23 (2), 123-132.

Walling, D.E. \& Zhang, Y. 2010. A National Assessment of Soil Erosion Based on Caesium137 Measurements. Advances in GeoEcology 41, 89-97.

Watson, A. \& Evans, R. 1991. A comparison of estimates of soil erosion made in the field and from photographs. Soil and Tillage Research 19, 17-27.

Watson, A. \& Evans, R. 2007. Water erosion of arable fields in North-East Scotland, 19852007. Scottish Geographical Journal 123, 107-121.

Zapata, F. (ed). 2002. Handbook for the Assessment of Spoil Erosion and Sedimentation Using Environmental Radionuclides. Dordrecht, Kluwer, 219 pp. 
Table 1. Percentage area of farmland, or the number of fields affected in any one year, when erosion was considered more widespread and severe than normal.

Table 2. Percentage area of farmland, or number of fields/sites eroded, in Britain over a period of years.

Table 3. Number of years fields eroded on the South Downs, Sussex, 1982-1991 (after Boardman, 2015)

Table 4. Number of years fields eroded in the Sompting catchment, South Downs, Sussex, 1991-2006 (after Evans, 2010b).

Table 5. Comparison of rates $\left(\mathrm{m}^{3} / \mathrm{ha}\right.$; $\left.\mathrm{t} / \mathrm{ha}\right)$ of erosion for monitored landscapes/sites in Britain (after Evans, 2005 and Boardman, 2015).

Table 6. Rates of erosion for locations that were not part of monitoring schemes in Britain.

Table 7. Occurrence, risk of occurrence and rates of rill erosion in arable fields. (Data derived From SSEW monitored transects 1982-1986).

Table 8. Erosion in the Swiss Midlands 1997/8-2006/7 (after Prasuhn, 2011 \& 2012).

Table 9. Soil associations in England and Wales most at risk of erosion (after Evans, 1990). 


\section{Figures}

Figure 1. Map of water erosion risk of lowland soil landscapes, after Evans, 1990. Mod risk: Mean area/year covered by eroded fields - 1-5\% farmland. Generally lower rates of erosion $\left(<2 \mathrm{~m}^{3} / \mathrm{ha} ;<2.6 \mathrm{t} / \mathrm{ha}\right)$. High risk: Mean area/year covered year by eroded fields $-5-10 \%$ farmland. Rates of erosion can be low or high. Very high risk: Mean area covered/year by eroded fields $>10 \%$ farmland. Generally higher rates of erosion $\left(>2 \mathrm{~m}^{3} / \mathrm{ha} ;>2.6 \mathrm{t} / \mathrm{ha}\right)$.

Figure 2a. Extent of eroded fields on transects monitored in the SSEW project 1982-86. Key: Salop-Shropshire; Notts-Nottinghamshire; Norf E- Norfolk East; IoW-Isle of Wight; Suss $\mathrm{W}^{* *}$-Sussex West; Staffs-Staffordshire; Norf W-Norfolk West; Somerset; Hants-Hampshire; Dorset; Gwent; Bedford-Bedfordshire; Kent; Hereford-Herefordshire; Suss E*-Sussex East; Cumbria*; Devon*-Devonshire. * Photographed 4 out of 5 years. ** Photographed 3 out of 5 years.

Figure $2 \mathrm{~b}$. Extent of eroded fields in soil landscapes within the monitored transects, SSEW monitoring project 1982-86. Key: Notts 2-Nottinghamshire, sandy textured soil associations; IoW 2-Isle of Wight, coarse loamy; Salop-Shropshire, sandy; Staffs 2-Staffordshire, sandy; Norf E-Norfolk East, sandy and coarse loamy; Suss W 2**-Sussex West, silty; Hants 2Hampshire, loamy; Norf W-Norfolk West, loamy; Somer 2-Somerset, silty; Notts 3Nottinghamshre, silty; Suss W3**-Sussex West, fine loamy; Dorset-Dorset, clayey; GwentGwent, loamy; IoW 3-Isle of Wight, loamy; Beds-Bedfordshire, clayey; Staffs 3Staffordshire, loamy; Kent-Kent, silty; Hereford-Herefordshire, silty; Notts 4Notttinghamshire, clayey; Suss E*-Sussex East, silty; Cumbria*; Hants 3-Hampshire, loamy; Devon*-Devonshire, loamy; Somer 3-Somerset, loamy. * Photographed 4 out of 5 years. ** Photographed 3 out of 5 years. 
Figure 2c. Maximum area of farmland (land not built on or wooded) in a soil association affected by erosion over the period 1982-1986. Key: Notts 2-Nottinghamshire, sandy textured soil associations; Hants 2-Hampshire, loamy; IoW 2-Isle of Wight, coarse loamy; Staffs 2 Staffordshire, sandy; Salop-Shropshire, sandy; Norf E-Norfolk East, sandy and coarse loamy; Suss W 2**-Sussex West, silty; Somer 2-Somerset, silty; Norf W-Norfolk West, loamy; Notts 3-Nottinghamshre, silty; Suss W3**-Sussex West, fine loamy; Staffs 3-Staffordshire, loamy; Hereford-Herefordshire, silty; IoW 3-Isle of Wight, loamy; Dorset-Dorset, clayey; Beds-Bedfordshire, clayey; Notts 4-Notttinghamshire, clayey; Gwent-Gwent, loamy; KentKent, silty; Cumbria*-Cumbria, sandy and loamy; Hants 3-Hampshire, loamy; Suss E*_Sussex East, silty; Devon*-Devonshire, loamy; Somer 3-Somerset, loamy.

Figure 3. Frequency of soil erosion - SSEW monitoring scheme, 1982-1986.

Figure 4a. Mean and median rates $\left(\mathrm{m}^{3} / \mathrm{ha}\right)$ of soil erosion per SSEW (1982-1986) monitored transect and all transects. Key: All-All transects; IoW-Isle of Wight; Somerset; Hants-

Hampshire; Kent; Salop-Shropshire; Staffs-Staffordshire; Notts-Nottinghamshire; Cumbria*; Devon*-Devonshire: Dorset; Hereford-Herefordshire; Gwent; Suss W**-Sussex West; Norf E- Norfolk East; Norf W-Norfolk West; Suss E*-Sussex East; Bedford-Bedfordshire.* Photographed 4 out of 5 years. ** Photographed 3 out of 5 years.

Figure 4 b. Mean and median rates $\left(\mathrm{m}^{3} / \mathrm{ha}\right)$ of soil erosion in soil associations with $>30$ eroded fields - SSEW monitoring project, 1982-1986. Key: IoW571g-Isle of Wight, coarse loamy and sandy soils; Som541m-Somerset, silty soils; Hants571i-Hampshire, loamy soils; Staffs551a-Staffordshire, sandy and coarse loamy soils; Som572i-Somerset, silty soils; Shr551d-Shropshire, sandy and coarse loamy soils; Staffs551g-Staffordshire, sandy soils; Shr551a-Shropshire, sandy and coarse loamy soils; Notts551b-Nottinghamshire, sandy and coarse loamy soils; Gw541a-Gwent, fine loamy soils; Here571b-Herefordshire, fine silty 
soils; Dorset411b-Dorset, clayey soils; Gw571b-Gwent, fine silty; NorW343g-Norfolk West, coarse loamy and sandy soils; NorE541g-Norfolk East, coarse loamy soils; NorE541t-

Norfolk East, coarse loamy soils; SusW343h-Sussex West, silty soils; NorW581f-Norfolk

West, coarse loamy and sandy soils; Beds411d-Bedfordshire, clayey soils.

Figure 4c. Maximum rates $\left(\mathrm{m}^{3} / \mathrm{ha}\right)$ of soil erosion in each SSEW monitored transect, 19821986. Key: IoW-Isle of Wight; Staffs-Staffordshire; Notts-Nottinghamshire; Somerset; Salop-Shropshire; Hants-Hampshire; Dorset; Gwent; Norf W-Norfolk West; Cumbria*; Kent; Hereford-Herefordshire; Devon*-Devonshire; Suss W**-Sussex West; Norf E- Norfolk; Suss E*-Sussex East; Bedford-Bedfordshire. * Photographed 4 out of 5 years. ** Photographed 3 out of 5 years.

Figure 5. Magnitude/frequency curves for the 17 SSEW monitored localities. Key: BedsBedfordshire; Cumbria; Devon-Devonshire; Dorset; Gwent; Hants-Hampshire; HerefordHerefordshire; IoW-Isle of Wight; Kent; Norf E - Norfolk East; Norf W-Norfolk West; Notts-Nottinghamshire; Salop-Shropshire; Somerset; Staffs-Staffordshire; Suss E-Sussex East; Suss W-Sussex West. 


\section{Description}

574

Monitored c.558 ha, winter 2006/7,

Kirkbride \& Reeves, 1993

Scotland.

*rilled fields, but $22 \%$ showed signs of erosion.

Sussex greensand.

Monitored 200 fields, winter 1982/3,

Somerset, silty soils

Monitored 208 fields, 1993, Strathearn,

Scotland.

Monitored 195 fields, 1992, Forfar,
584

585

586

587 
Boardman, 2015

Harrod, 1998

Watson \& Evans, 2007

Monitored 1989-1994. 80 fields in 13 localities, various soil types.

Monitored 1967-1976. Shropshire, sandy soils.

Monitored 1982-1987. Sussex, South Downs, chalky and silty soils. Monitored 1982-1991. Sussex, South, Downs, chalky and silty soils, 122 fields. Monitored 1996-1998. 772 sites, many soil types.

Monitored 13 years. 5244 fields, Eastern Scotland

Monitored 8 years. 4393 fields, Eastern Scotland.

Monitored 6 years. 1375 fields, Eastern

Scotland.

Table 2. Percentage area of farmland, or number of fields/sites eroded, in Britain over a period of years. 
$\%$ total no.

field eroded

eroded fields

1982-1987 1982-1991

$59.6 \quad 53.6$

$21.0 \quad 17.9$

$10.5 \quad 17.9$

$6.1 \quad 7.1$

$2.6 \quad 3.6$

Table 3. Number of years fields eroded on the South Downs, Sussex, 1982-1987 (after Boardman, 1990) and 1982-1991 (after Boardman, 2015). 
No. years

field eroded

1

2

3

4

5

6

7

8

10

11

12

13

14

15

16
$\%$ total no.

\section{eroded fields}

16.1

16.1

16.1

3.2

3.2

6.5

3.2

3.2

6.5

12.9

6.5

3.2

3.2

Table 4. Number of years fields eroded in the Sompting catchment, South Downs, Sussex, 1991-2006 (after Evans, 2010b). 
644 (Reference)

$\mathrm{m}^{3} / \mathrm{ha}\left(\mathrm{t} / \mathrm{ha}^{*}\right)$

annual values

annual values

645

$<0.01-173.1$

$\mathrm{m}^{3} / \mathrm{ha}(\mathrm{t} / \mathrm{ha}$ *)

$\mathrm{m}^{3} / \mathrm{ha}\left(\mathrm{t} / \mathrm{ha}^{*}\right)$

647

ADAS 1990-1994

$(<0.01-225.0)$

$0.5-5.2$

0.2-1.7

649

(Chambers et al., 1992; Chambers \& Garwood, 2000)

SSLRC 1996-1998**

$<0.01-16.6$

$0.1-1.5$

0.01-0.6

652

$(<0.01-21.6)$

$(0.1-1.9)$

$(0.01-0.8)$

653

(Harrod, 1998)

654

South Downs 1982-1991

$0.01-234$

$0.4-23.1$

$0.5-5.0$

655

(0.01-304.2)

$(0.5-30.0)$

$(0.6-6.5)$

(Boardman, 2003)

$(\mathrm{t} / \mathrm{ha} *)$ - assuming soil bulk density $=1.3 \mathrm{~g} / \mathrm{cm}^{3}$

** 'Unchanneled' erosion included in this data

Table 5. Comparison of rates $\left(\mathrm{m}^{3} / \mathrm{ha}\right.$; $\left.\mathrm{t} / \mathrm{ha}\right)$ of erosion for monitored landscapes/sites in

Britain (after Evans, 2005 and Boardman, 2015). 


\section{Reference}

Deasy et al., 2010

Silgram et al., 2010

Colborne \& Staines, 1986

$(0.1-19.5)$

Colborne \& Staines, 1985

0.2-4.3

(0.3-5.6)

Wade \& Kirkbride, 1998

$0.6-9.8$

$(0.8-12.5)$

1.3-187.2

$(1.7-243.4)$

38.2

(49.7)

\section{Description}

52 unbounded plots, various locations and

soil types, 2005-2008.

Maximum rates, 2 sites in West Midlands,

2005-2007

20 fields, silty and clay soils, Somerset and

Dorset, 1984-1985.

40 fields, silty soils, Somerset, 1982-1983.

Catchments in 3 fields, Fife, Scotland, 1993.

11 fields, eastern Scotland, 1985-1986.

One field, West midlands, 1996.

\footnotetext{
*Assuming soil bulk density of $1.3 \mathrm{~g} / \mathrm{cm}^{3}$
}

Table 6. Rates of erosion for locations that were not part of monitoring schemes in Britain. 
681

682

683

684

685

686

687

689

690

691

692

693

694

695

696

697
Risk of occurrence erosion* Mean rate erosion

crop type risk $\mathrm{m}^{3} / \mathrm{ha} \quad \mathrm{t} / \mathrm{ha}^{* *}$

Winter cereal $\quad 42.8$

Hops 1 field in $6 \quad 3.92 * * * \quad \mathbf{5 . 1 0} * * *$

Sugar beet $\quad 18.4$

Sugar beet

1 field in $7 \quad 3.04 * * *$

$3.95 * * *$

Spring cereal $\quad 11.5$

Maize

1 field in $7 \quad \mathbf{4 . 4 8} * * *$

$5.82 * * *$

Potatoes $\quad 10.6$

Potatoes

1 field in $10 \quad \mathbf{2 . 5 3}^{* * *}$

3.29***

Field veg. $\quad 6.3$

Other

1 field in 11

$2.83 * * *$

$3.68 * * *$

Other $\quad 3.0$

Field veg.

1 field in 14

$5.08 * * *$

$6.60 * * *$

Maize $\quad 1.6$

Bare soil

1 field in 21

1.61

2.09

Bare soil $\quad 1.5$

Kale

1 field n $24 \quad 2.10$

2.73

Oilseed rape $\quad 1.5$

Ley grasses

1 field in 32

4.09***

$5.32 * * *$

Peas 1.0

Spring cereal

1 field in $34 \quad 1.75$

2.27

Kale $\quad 0.7$

Peas

1 field in $38 \quad 1.2$

1.57

Hops

0.5

Winter cereal 1 field in $42 \quad 1.85$

2.40

Field beans $\quad 0.4$

Field beans

1 field in $71 \quad 0.47$

0.61

Ley grasses $\quad 0.2$

Oilseed rape $\quad 1$ field in $100 \quad 1.92$

2.50
$* *$ Assuming soil bulk density $=1.3 \mathrm{~g} / \mathrm{cm}^{3} \quad * * *$ Higher rates erosion

Table 7. Occurrence, risk of occurrence and rates of rill erosion in arable fields. (Data derived from SSEW monitored transects 1982-1986). 


\begin{tabular}{|c|c|c|c|c|c|}
\hline 701 & Cropping & $\%$ area & Erosion & $\%$ total & Mean rate \\
\hline 702 & & & Selected crops & erosion & $(\mathrm{t} / \mathrm{ha} / \mathrm{yr})$ \\
\hline 703 & Winter wheat & 23 & Winter wheat & 33 & 1.05 \\
\hline 704 & Ley & 21 & Potatoes & 26 & 2.87 \\
\hline 705 & Maize & 15 & Fallow (after potatoes) & 14 & 1.06 \\
\hline 706 & Sugar beet & 14 & Maize & 10 & 0.44 \\
\hline 707 & Winter barley & 9 & Sugar beet & 5 & 0.27 \\
\hline 708 & Potatoes & 6 & Winter barley & 4 & 0.34 \\
\hline 709 & Rape & 2 & Ley & 2 & 0.07 \\
\hline 710 & Other & 10 & & & \\
\hline 711 & \multicolumn{5}{|c|}{ Extent of erosion - mean area eroded per year $-32.2 \%$} \\
\hline 712 & \multicolumn{5}{|c|}{ Area of field affected by erosion $-16 \%$ (range $7-37 \%$ ) } \\
\hline 713 & \multicolumn{5}{|c|}{ Mean rate of erosion whole area $-0.75 / \mathrm{ha} / \mathrm{yr}$ (range $0.16-1.83 \mathrm{t} / \mathrm{ha} / \mathrm{yr}$ ) } \\
\hline 714 & \multicolumn{4}{|c|}{ Maximum rate $-58 \mathrm{t}$ ha/yr } & \\
\hline 715 & \multicolumn{5}{|c|}{ Frequency of erosion: None $-12 \% ; x 1-19 \% ; x 2-15 \% ; x 3-14 \% ; x 4-13 \%$} \\
\hline 716 & \multirow{2}{*}{\multicolumn{5}{|c|}{$x 5-9 \% ; x 6-7 \% ; x 7-5 \% ; x 8-2 \% ; x 9-3 \% ; x 10-1 \%$}} \\
\hline 717 & & & & & \\
\hline 718 & \multicolumn{5}{|c|}{ Frequency distribution curve as other studies } \\
\hline 19 & Channel erosio & ash - & & & \\
\hline
\end{tabular}

720 Table 8. Erosion in the Swiss Midlands 1997/8-2006/7 (after Prasuhn, 2011 \& 2012). 
Symbol

$551 b$

Newport 1

725

$541 \mathrm{~s}$

$551 \mathrm{c}$

$551 \mathrm{e}$

$554 \mathrm{a}$

$571 d$

$571 \mathrm{e}$

$343 \mathrm{~h}$

$571 \mathrm{~g}$

Cuckney 1

Bridgnorth

Bearsted 1

Bromsgrove

South Petherton

Wick 2

Cuckney 2

Newport 2

Frilford

Fyfield 1

Fyfield 2

Andover 1

Fyfield 4
Sandy and coarse loamy

Dominant soil texture

Sandy and coarse loamy

Sandy and coarse loamy

Coarse loamy and sandy

Coarse loamy

Silty

Coarse loamy

Sandy and fine loamy

Sandy

Sandy and coarse loamy

Coarse and fine loamy

Coarse loamy and sandy

Silty

Coarse loamy and sandy

Table 9. Soil associations in England and Wales most at risk of erosion (after Evans, 1990). 


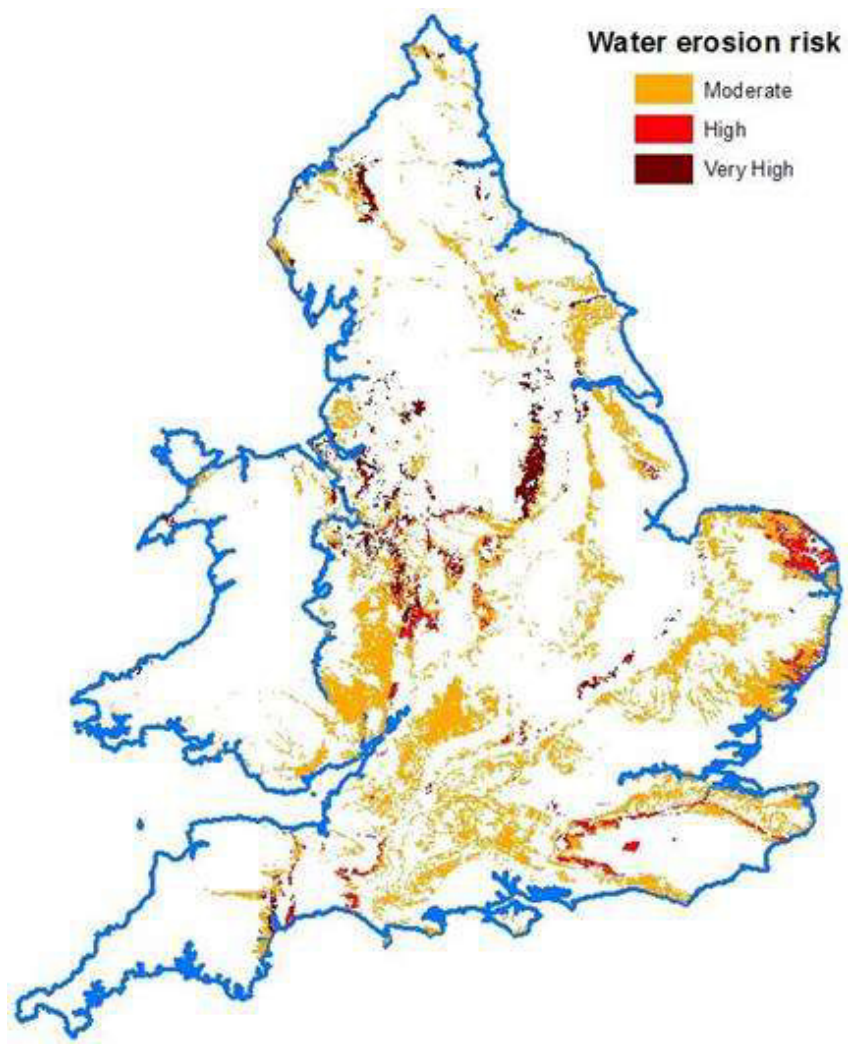

Figure 1. Map of water erosion risk of lowland soil landscapes, after Evans, 1990. Mod risk: Mean

area/year covered by eroded fields - 1-5 \% farmland. Generally lower rates of erosion $\left(<2 \mathrm{~m}^{3} / \mathrm{ha} ;<\right.$

2.6 t/ha)). High risk: Mean area/year covered year by eroded fields - 5-10 \% farmland. Rates of

erosion can be low or high. Very high risk: Mean area covered/year by eroded fields $>10 \%$

farmland. Generally higher rates of erosion ( $>2 \mathrm{~m}^{3} / \mathrm{ha} ;>2.6 \mathrm{t} / \mathrm{ha}$ ). 


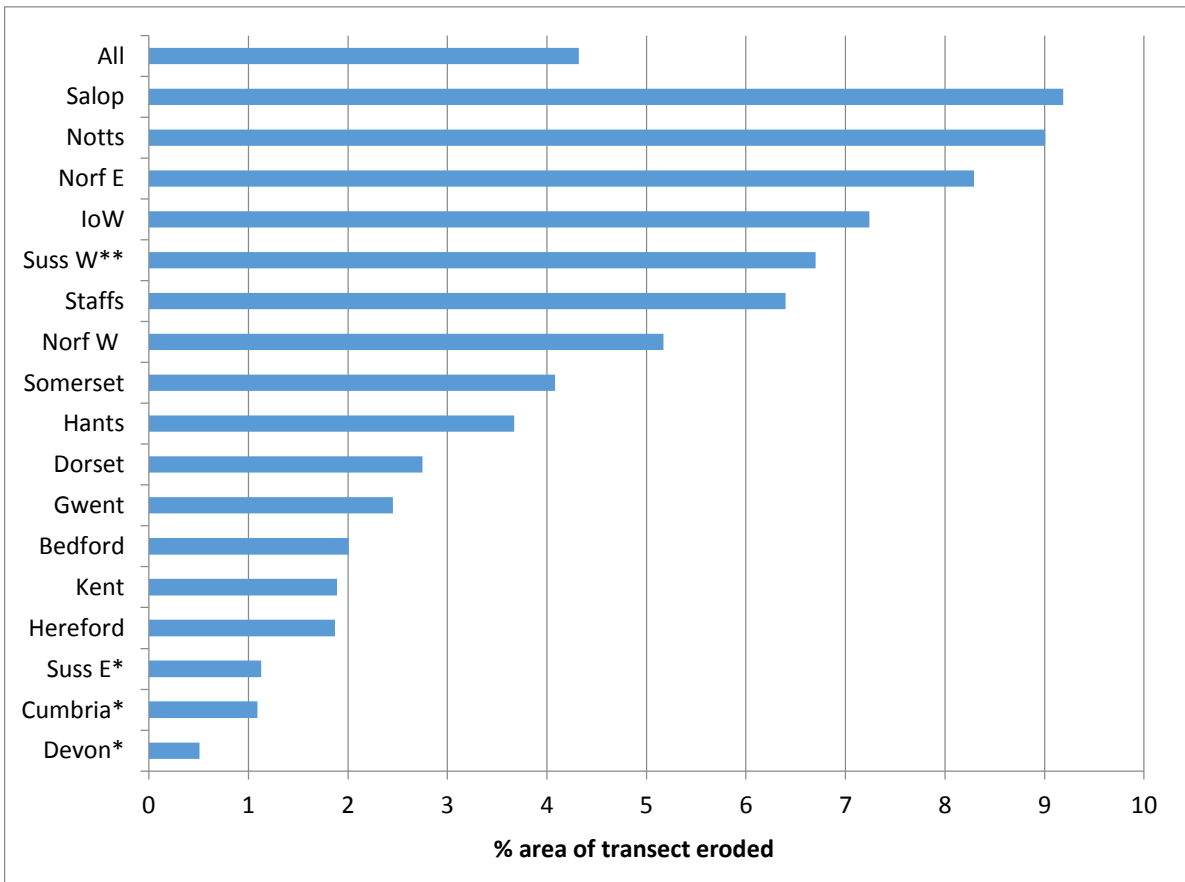

Figure 2a. Extent of eroded fields on transects monitored in the SSEW project 1982-86. Key: Salop-

Shropshire; Notts-Nottinghamshire; Norf E- Norfolk East; loW-Isle of Wight; Suss W**-Sussex West;

Staffs-Staffordshire; Norf W-Norfolk West; Somerset; Hants-Hampshire; Dorset; Gwent; Bedford-

Bedfordshire; Kent; Hereford-Herefordshire; Suss E*-Sussex East; Cumbria*; Devon*-Devonshire.

* Photographed 4 out of 5 years. ** Photographed 3 out of 5 years. 


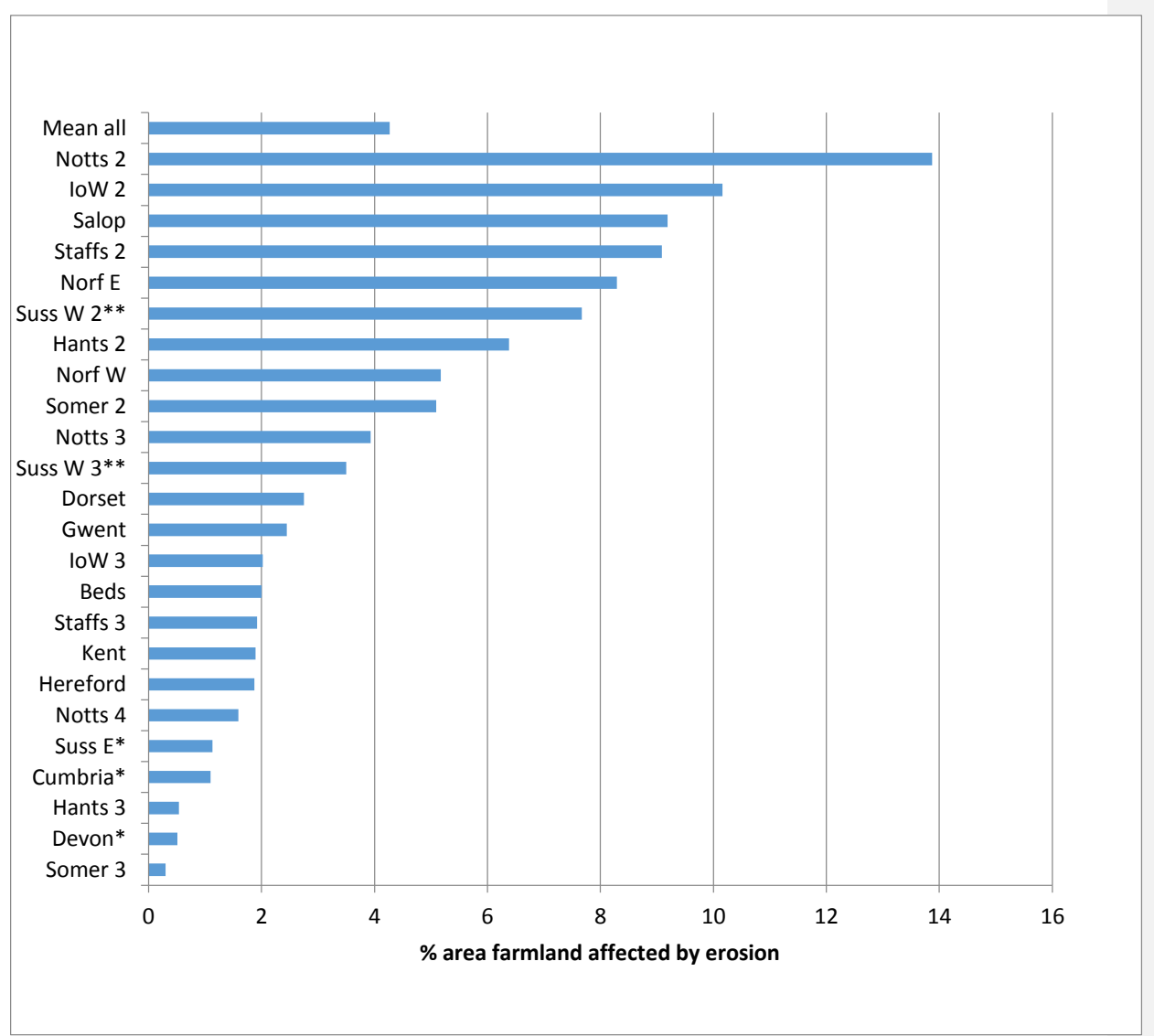

Figure $2 b$. Extent of eroded fields in soil landscapes within the monitored transects, SSEW

monitoring project 1982-86. Key: Notts 2-Nottinghamshire, sandy textured soil associations; loW 2 -

Isle of Wight, coarse loamy; Salop-Shropshire, sandy; Staffs 2-Staffordshire, sandy; Norf E-Norfolk

East, sandy and coarse loamy; Suss W $2^{* *}$-Sussex West, silty; Hants 2-Hampshire, loamy; Norf W-

Norfolk West, loamy; Somer 2-Somerset, silty; Notts 3-Nottinghamshre, silty; Suss W3**-Sussex

West, fine loamy; Dorset-Dorset, clayey; Gwent-Gwent, loamy; loW 3-Isle of Wight, loamy; Beds-

Bedfordshire, clayey; Staffs 3-Staffordshire, loamy; Kent-Kent, silty; Hereford-Herefordshire, silty; 


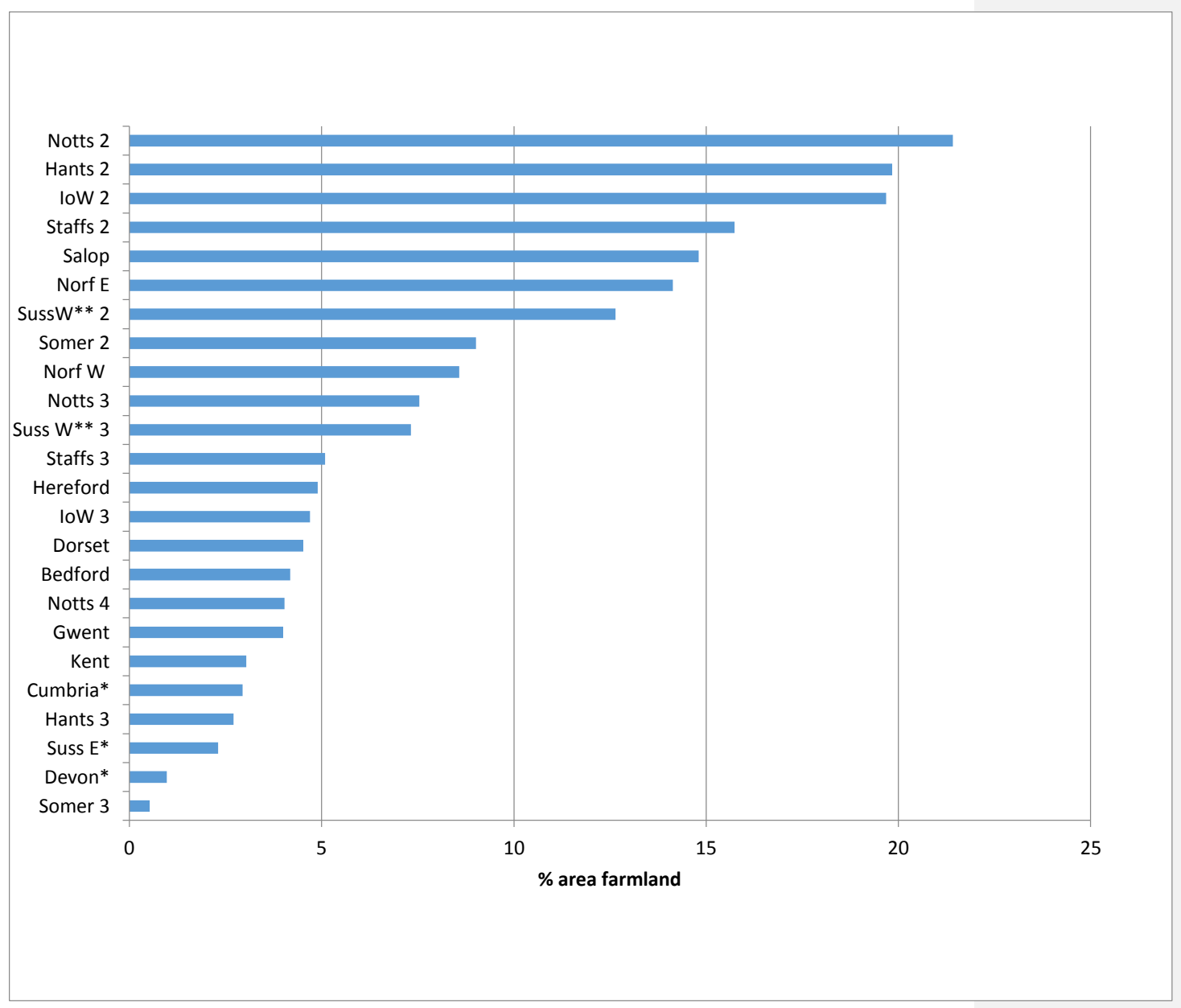

1986. Key: Notts 2-Nottinghamshire, sandy textured soil associations; Hants 2-Hampshire, loamy;

IoW 2-Isle of Wight, coarse loamy; Staffs 2-Staffordshire, sandy; Salop-Shropshire, sandy; Norf E-

Norfolk East, sandy and coarse loamy; Suss W $2^{* *}$-Sussex West, silty; Somer 2-Somerset, silty; Norf

W-Norfolk West, loamy; Notts 3-Nottinghamshre, silty; Suss W3**-Sussex West, fine loamy; Staffs 3-

Staffordshire, loamy; Hereford-Herefordshire, silty; loW 3-Isle of Wight, loamy; Dorset-Dorset, 


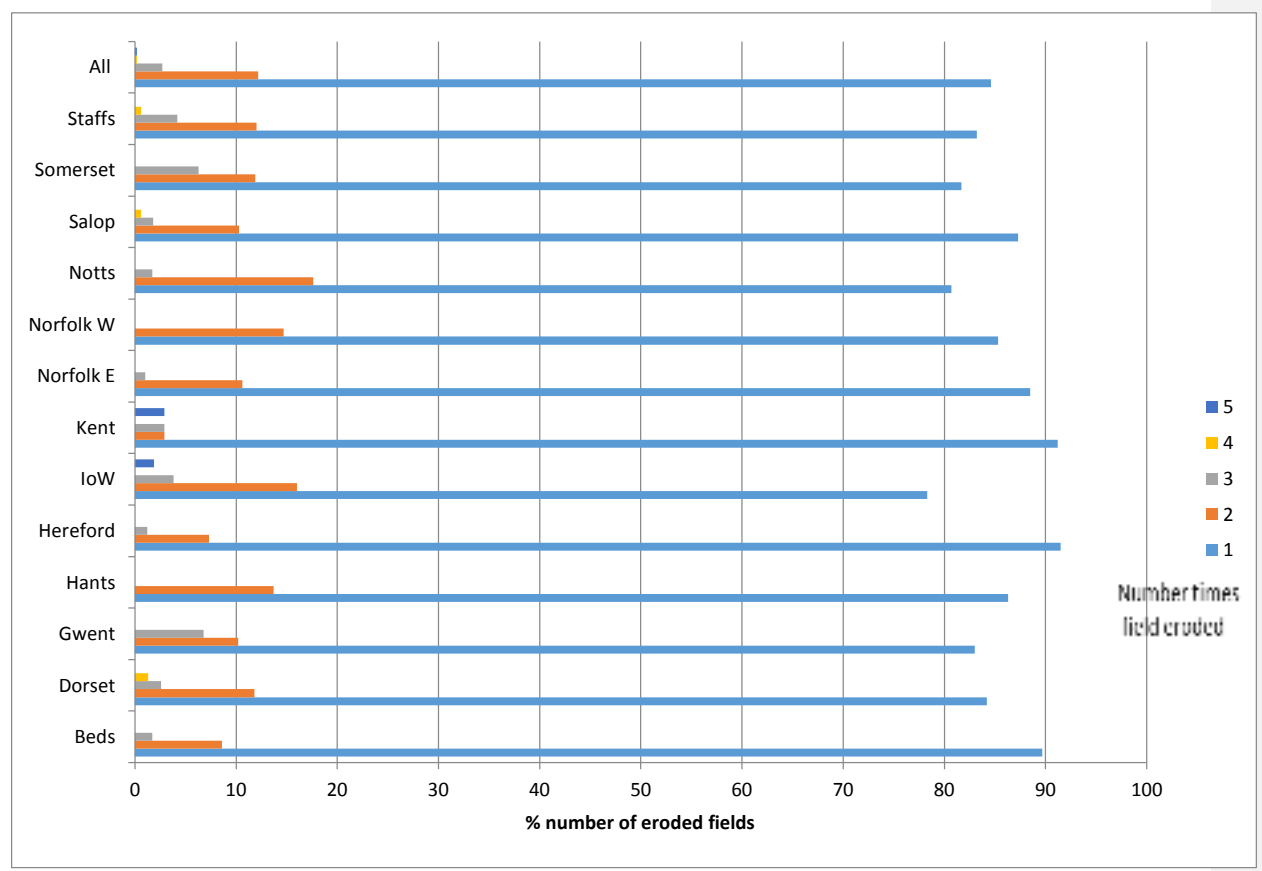

Figure 3. Frequency of soil erosion - SSEW monitoring scheme, 1982-1986.

798

799

800

801

802

803

804

805

806 


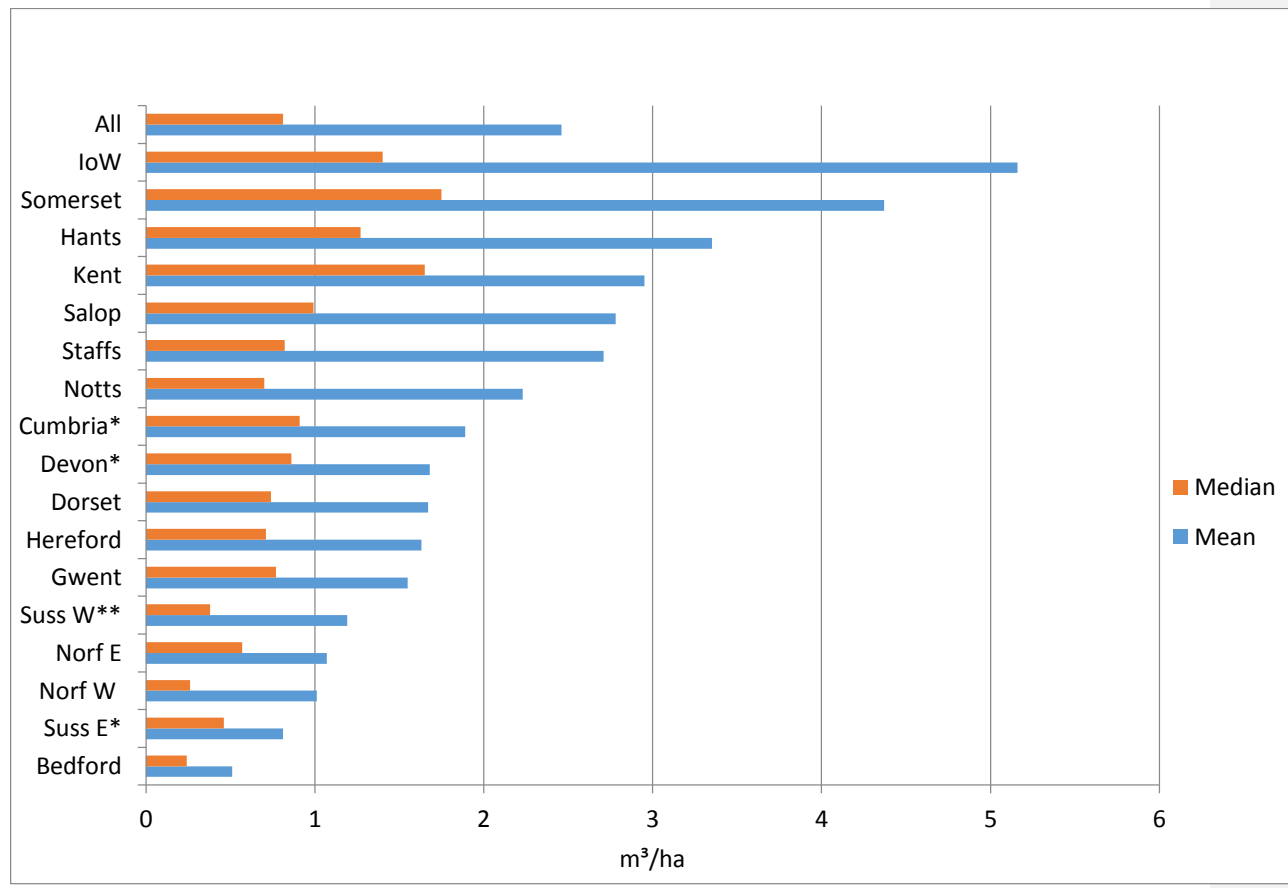

Figure 4a. Mean and median rates ( $\mathrm{m}^{3} / \mathrm{ha}$ ) of soil erosion per SSEW (1982-1986) monitored transect

and all transects. Key: All - All transects; loW-Isle of Wight; Somerset; Hants-Hampshire; Kent; Salop-

Shropshire; Staffs-Staffordshire; Notts-Nottinghamshire; Cumbria*; Devon*-Devonshire: Dorset;

Hereford-Herefordshire; Gwent; ; Suss W**-Sussex West; Norf E- Norfolk East; Norf W-Norfolk West; of 5 years. 


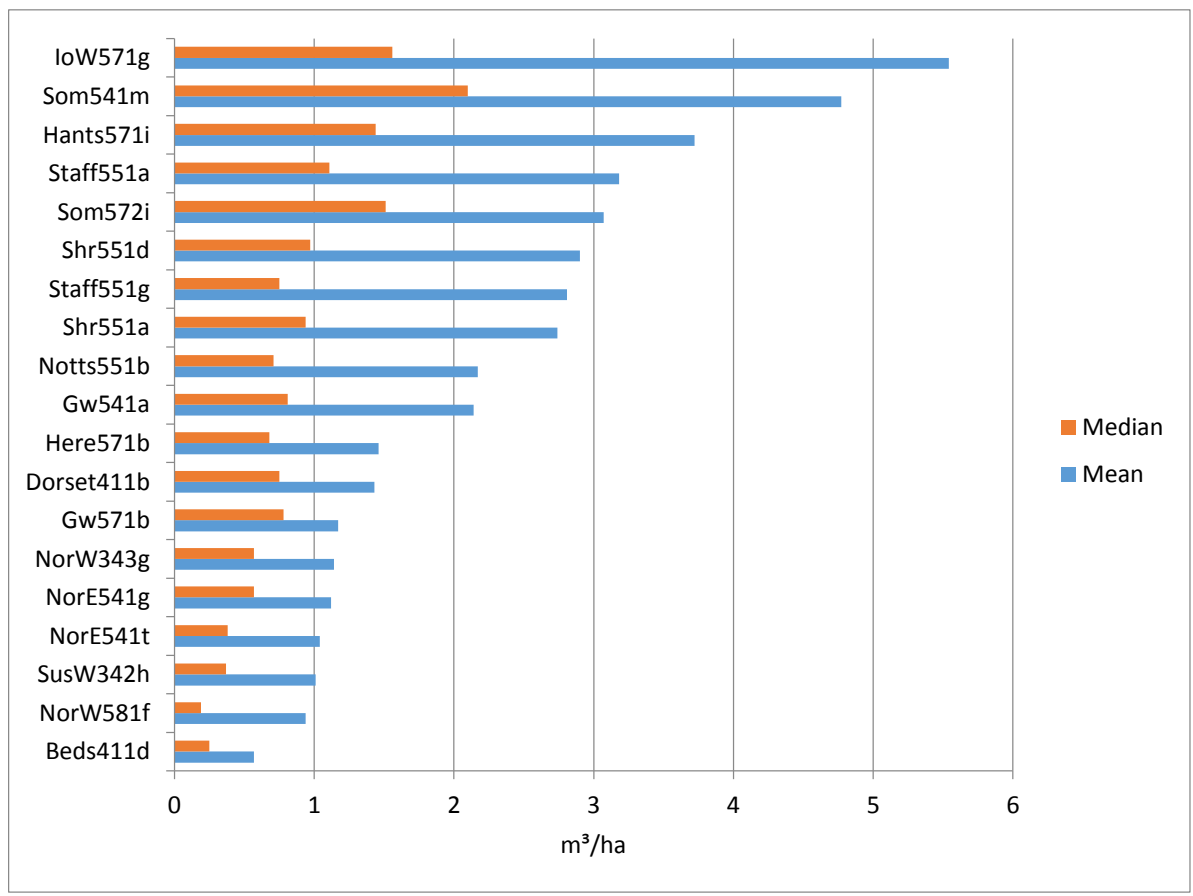

Figure $4 \mathrm{~b}$. Mean and median rates $\left(\mathrm{m}^{3} / \mathrm{ha}\right)$ of soil erosion in soil associations with $>30$ eroded fields

- SSEW monitoring project, 1982-1986. Key: loW571g-Isle of Wight, coarse loamy and sandy soils; and coarse loamy soils; Som572i-Somerset, silty soils; Shr551d-Shropshire, sandy and coarse loamy soils; Staffs551g-Staffordshire, sandy soils; Shr551a-Shropshire, sandy and coarse loamy soils; Notts551b-Nottinghamshire, sandy and coarse loamy soils; Gw541a-Gwent, fine loamy soils; Here571b-Herefordshire, fine silty soils; Dorset411b-Dorset, clayey soils; Gw571b-Gwent, fine silty; NorW343g-Norfolk West, coarse loamy and sandy soils; NorE541g-Norfolk East, coarse loamy soils; NorE541t-Norfolk East, coarse loamy soils; SusW343h-Sussex West, silty soils; NorW581f-Norfolk West, coarse loamy and sandy soils; Beds411d-Bedfordshire, clayey soils. 


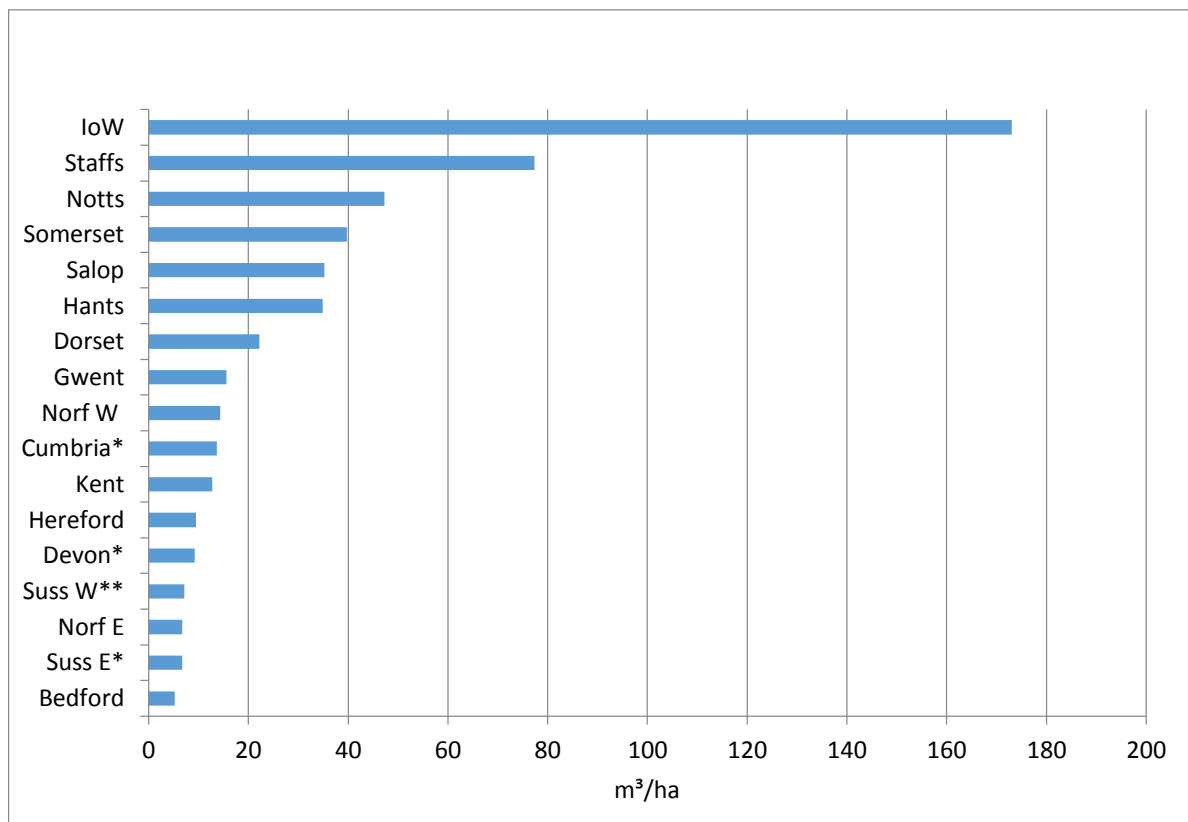

Figure 4c. Maximum rates ( $\mathrm{m}^{3} / \mathrm{ha}$ ) of soil erosion in each SSEW monitored transect, 1982-1986. 


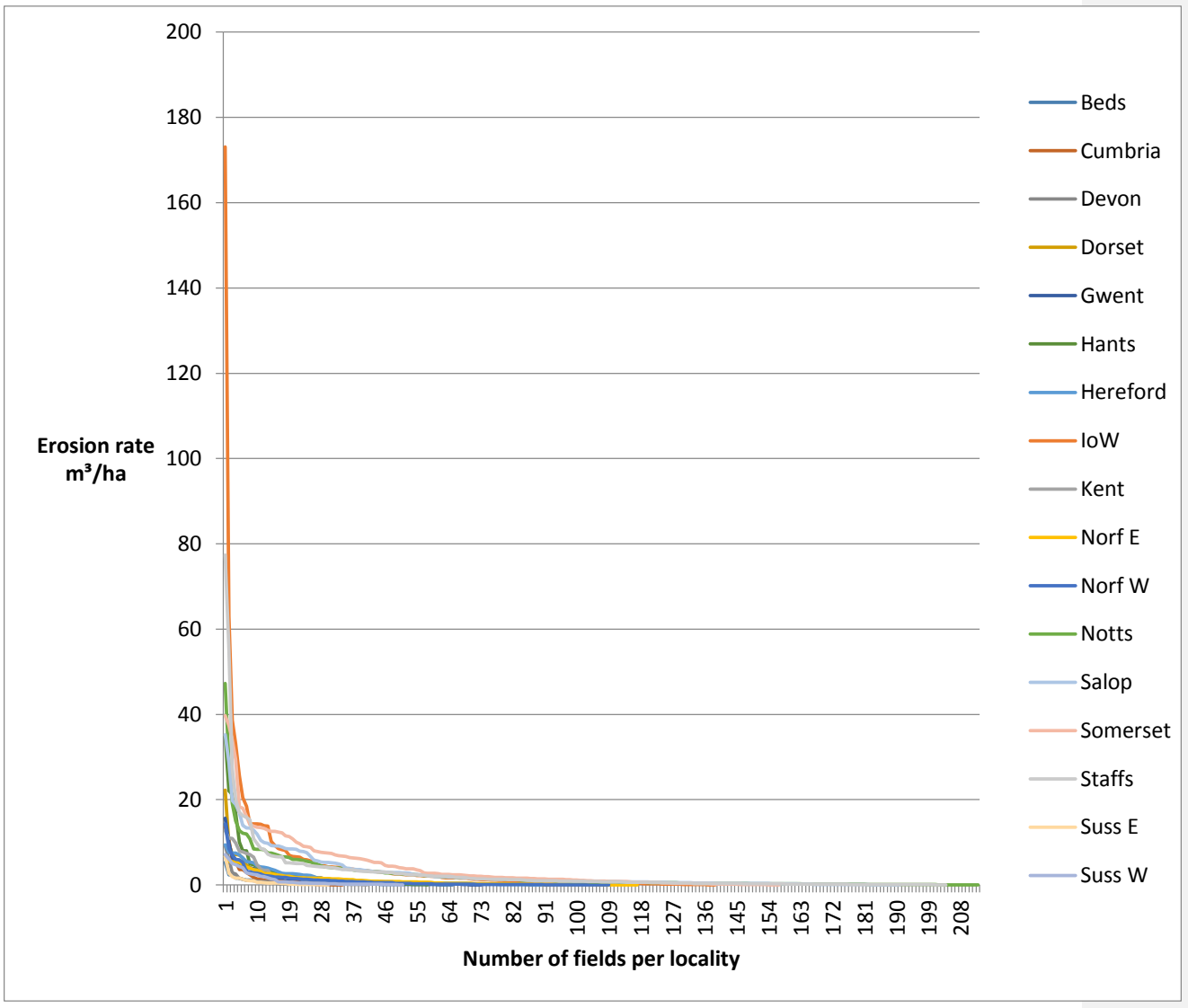

Figure 5. Magnitude/frequency curves for the 17 SSEW monitored localities. Beds-Bedfordshire;

Cumbria; Devon-Devonshire; Dorset; Gwent; Hants-Hampshire; Hereford-Herefordshire; loW-Isle of

Wight; Kent; Norf E - Norfolk East; Norf W-Norfolk West; Notts-Nottinghamshire; Salop-Shropshire;

Somerset; Staffs-Staffordshire; Suss E-Sussex East; Suss W-Sussex West. 